\title{
UV-B Radiations and Secondary Metabolites
}

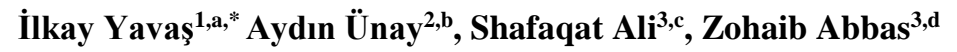 \\ ${ }^{1}$ Department of Plant and Animal Production, Koçarl Vocational School, Adnan Menderes University, 09100 Aydin, Turkey \\ ${ }^{2}$ Department of Field Crops, Faculty of Agriculture, Adnan Menderes University, 09100 Aydin, Turkey \\ ${ }^{3}$ Department of Environmental Sciences and Engineering, Government College University, Allama Iqbal Road, Faisalabad, 38000 Pakistan \\ ${ }^{*}$ Corresponding author

\begin{tabular}{l|l}
\hline A R T I C L E I N F O & A B S T R A C T \\
\hline Review Article & $\begin{array}{l}\text { Ultraviolet-B (UV-B: } 280 \text { to } 320 \mathrm{~nm} \text { ) radiations have appeared to be detrimental to plants, due to } \\
\text { their damaging effects on proteins, lipids, membranes and DNA. UV-B radiations are a significant } \\
\text { regulator of plants' secondary metabolites. High intensity of ultraviolet radiations may interfere with } \\
\text { growth and productivity of crops. But low levels of UV-B radiations give rise to changes in the } \\
\text { plants secondary metabolites such as phenolic compounds, carotenoids and glucoseinolates. } \\
\text { Theceived : } 11 / 08 / 2019 \\
\text { Accepted : } 17 / 12 / 2019 \\
\text { metabolites, having improved reproductive ability, early ripening and tolerance against fungi, } \\
\text { bacteria and herbivores. }\end{array}$
\end{tabular}

Keywords:

Carotenoids

Glucosinolates

Phenolic compounds

Secondary metabolites

Ultraviolet-B

\section{Introduction}

Ultraviolet-B (UV-B: 280 to $320 \mathrm{~nm}$ ) radiations are absorbed by stratospheric ozone $\left(\mathrm{O}_{3}\right)$ and a very small percentage is transmitted to the Earth's surface which is harmful to plants (Ravindran et al., 2010; Kumari and Prasad, 2013; Frohnmeyer and Staiger, 2003; Gupta, 2017; Klein et al., 2018). Secondary metabolites, like flavonoids, alkaloids, and lignin are UV-B absorbing compounds, which can preserve the genetic material of plants ( $\mathrm{Gu}$ et al., 2010; Katerova et al., 2012). Exposure of plants to UV-B radiations may cause changes in the production of secondary metabolites (Klein et al., 2018) and pigment composition (Delgado-Vargas et al., 2000). Kakani et al. (2003 b) stated that although the amount of UV-B radiations changed from 2 to $12 \mathrm{~kJ} \mathrm{~m}^{-2}$ per day, most of the UV-B studies were conducted under fairly high UV-B radiation levels (>15 $\mathrm{kJ} \mathrm{m}^{-2}$ per day), that are likely to be unusual in the future climates.
Ultraviolet wavelength $(400-200 \mathrm{~nm})$ refers to electromagnetic radiations between visible light and $\mathrm{X}$ rays, with significant influence on the living organisms, including plants (Katerova et al., 2012; Mao et al., 2017). Climate change refers to seasonal variations, defined as increased atmospheric temperatures, carbon dioxide concentrations and intensity of Ultraviolet-B radiations, having significant influences on plants (Teramura et al., 1990; Torres et al., 2016). UV-B (280-315 nm) radiations reach the Earth as a result of stratospheric ozone depletion due to pollutants.

The aim of this review is to evaluate the effects of elevated UV-B radiations on the secondary metabolites of plants. Moreover, yield and yield components, leaf morphology and anatomy, flowering and pollination of some important crops under elevated UV-B condition were also reviewed. 


\section{Crop Yield and Morphological Characters}

It is emphasized in the important crops such as pea, soybean and cotton that the most commonly observed morphological changes, due to UV-B radiations, include decreased leaf area or increased leaf thickness (Figure 1). Decrease in leaf area is attributed to reduction in size, number, division and expansion of cells. Together with the reduced leaf area, heliotropism reduced the amount of UV$\mathrm{B}$ radiations absorbed by the soybean leaves. (Gao et al., 2003; Gupta et al., 2017). Epicuticular wax content of cotton leaves was increased by elevated UV-B radiations but leaf thickness was reduced due to decrease in thickness of palisade and mesophyll tissue (Kakani et al., 2003 a). Shorter internodes are observed in UV-B treated pea plants as a consequence of reduction in number rather than cell length (Gonzalez et al. 1998). The tolerance to UV-B radiations has been considered as an important selection criterion by pea and rice breeders (Brosché and Strid, 2000; Hidema and Kumagai, 2006; Sharma, 2001). Besides Mao et al. (2017) have reported that elevated UV radiations significantly decreased soybean yield.

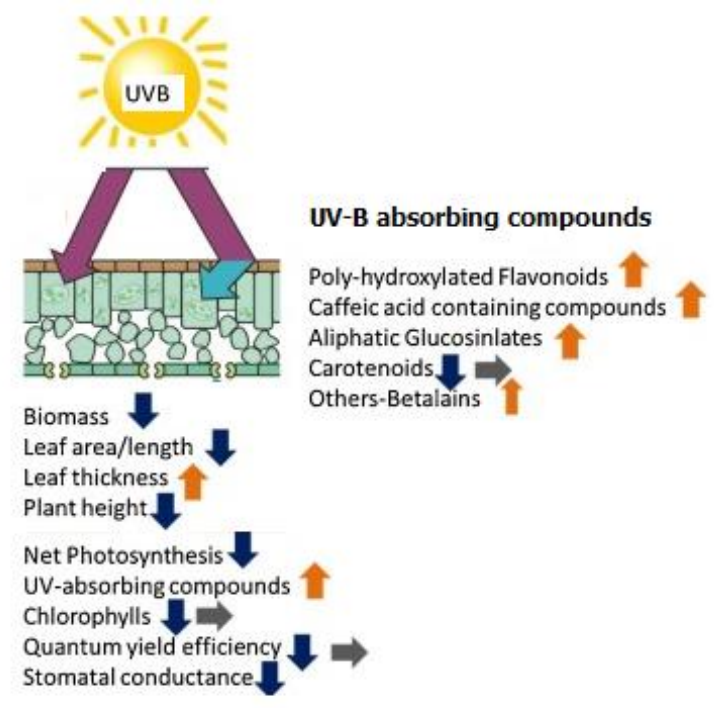

Figure 1 Changed from Verdaguer et al., 2017 and Neugart and Schreiner, 2018

Some researchers have emphasized that the reduction in root elongation, caused by UV-B radiations, was due to changes in photo hormones such as IAA (Mark and Tevini, 1996). Ultraviolet-B radiations can affect pollination directly or indirectly. Higher intensity of UV-B radiations delays the onset of flowering in annual plants with consequent reduction in fruit and/or seed production. Flower morphology, pollen production, pollen germination, pollen tube length and pollen morphology are adversely affected by elevated UV-B radiations. In addition, UV-B radiations in soybeans are associated with the effect of temperature, $\mathrm{CO}_{2}$ and other stressors (Koti et al., 2005). Plants on higher latitudes and longitudes, where UV levels are higher, show greater tolerance to UV radiation than those grown on plains.

UV-B radiation penetration is affected by photo chromes / crypto chromes, aromatic amino acids, DNA and phospholipids because they absorb UV-B to some degree.
The content of chlorophyll a, b and total chlorophyll decreases with increasing UV radiation level (Figure 1). As a result of decrease in photosynthetic pigments in plants, due to structural damage, a decrease in the rate of photosynthesis is observed. Besides, prolonged exposure of plants to UV-B radiations results in reduced yields. Quan et al. (2018) stated that the UV-B induced a decline in photosynthesis with consequent loss in leaf and stem biomass in Scutellaria baicalensis. High doses of UV-B radiations impede plant growth and development by limiting photosynthesis, overproduction of reactive oxygen species (ROS) and development of oxidative stress, which may decrease cell viability and ultimately can death of plants (Katerova et al., 2012; Mao et al., 2017). On the other hand, low UV-B doses may trigger acclimation responses in plants. Frohnmeyer and Staiger (2003) pointed out that low doses of UV-B induce photo morphogenesis in etiolated seedlings. Similarly, Katerova et al. (2012) observed enhanced production of secondary compounds in plants, exposed to low UV-B doses.

\section{Signalling and Perception of Uv-B Radiation}

Plants have the extensive ability to respond to the UVB exposure. Such kind of plant responses can be measured by (1) specific physiological and morphological changes (2) alternations in gene expression and (3) accumulation of definite secondary metabolites (Lake et al., 2009; Mewis et al., 2012). Plants possess five different kinds of sensory photoreceptors which help the plants precisely perceive the ambient light and generate the responses that prevent the damage and improve photosynthesis. These photoreceptors include UVB (UVR8) photoreceptor, phototropism, blue light-sensing crypto chromes, red/far-red light-sensing phytochromes and Zeitlupe (Heijde and Ulm, 2012). UVR8 is the most widely reported UV-B photoreceptor as stated by different researchers (Yin and Ulm, 2017; Yang et al., 2018).

UVR8 signalling considerably promotes the UV-B acclimation and establishment of UV-B tolerance (Gonzalez et al., 2012). UV-B acclimation is significantly linked with expression of UVR8-activated gene associated with the biosynthesis of flavonoids, protection against oxidative stress, photo inhibition and DNA repair (Favory et al., 2009; Stracke et al., 2010). Different physiological responses have been associated with the activity of UVR8 photoreceptor, including phototropism (Vandenbussche et al., 2014), stomatal opening (Tossi et al., 2014), leaf development (Wargent et al., 2009) downward leaf curling (Fierro et al., 2015), salt stress tolerance (Fasano et al., 2014), shade avoidance responses (Hayes et al., 2014; Mazza and Ballare, 2015), thermos morphogenesis (Hayes et al., 2017), auxin signalling (Hayes et al., 2014) and UV-B signalling influencing defence responses (Demkura et al., 2012). UVR8 photoreceptor exists as active homodimer in cytosol which is quickly monomerized during UV-B absorption, where tryptophan residue act as chromophores UV-B. Monomer of the UVR8 receptor, induced by UV-B, then straightaway react with E3 ubiquitin ligase CONSTITUTIVELY PHOTOMORPHOGENIC 1 (COP1), thereby starting signal pathways that transduce changes in gene expression (Favory et al., 2009; Christie et al., 2012; Wu et al., 2012). Downstream of COP 1 and UVR8, the 
bZIP transcription factors HY5 HOMOLOG $(\mathrm{HYH})$ and ELONGATED HYPOCOTYL 5 (HY5) are needed for the obvious regulation of UV-B regulated genes (Stracke et al., 2013; Binkert et al., 2014). WD40 repeat gene protein REPRESSOR OF UV-B PHOTOMORPHOGENESIS 1 (RUP1) and REPRESSOR OF UV-B PHOTOMORPHOGENESIS 2 (RUP2) are quickly and briefly encourage by UV-B irradiation in COP1, UVR8 and HY5-Dependent Way (Gruber et al., 2010). Both RUP1 and RUP2 perfectly interact with UVR8 to enable the reversion of UVR8 monomers to homodimers in order to stabilize the signal pathways (Gruber et al., 2010; Heijde et al., 2013).

\section{Uv-B Radiation Stress and Plant Response}

Upon continuous UV-B exposure, plants usually display weakened metabolic stress response due to governing feedback loops. This exposure subsequently increases the accumulation of stress-induced metabolites (Höll et al., 2019). Response of plants to stresses creates considerable metabolic cost. Subsequently, adaption in metabolic processes are usually accompanied by deceptive growth penalties (Herms \& Mattson, 1992). Exposure to UV-B radiations is one of the most destructive factors due to their subsequent interaction with biological molecules such as proteins, nucleic acid, photo hormones and lipids, with subsequent decline in overall performance of plants (Kataria et al., 2014). Exposure to UV-B radiations affects the growth of plants, yield, physiological processes, morphology, DNA and denaturation of proteins. Dose and proportion of UV-B radiations are critical factors regarding the plant responses. Spectral balance between UV-B and photo synthetically active radiations (PAR) is also an important factor in determining plants' sensitivity (Sharma et al.,2017). Particularly, PAR can alleviate negative effects of enhanced exposure of plants to UV-B radiation (Nithia et al. 2005).

Plants have developed protective mechanisms to combat the heightened UV-B irradiance by safeguarding the sensitive targets (Rizzini et al.,2011). UV-B radiations provoke the generation of reactive oxygen species (ROS) through nicotinamide adenine dinucleotide phosphate (NADPH) oxidase in different cellular components like mitochondria (Huang et al., 2016) and chloroplasts (Dietz et al., 2016). Over-generation of ROS in plants, as a consequence of excessive exposure to UV-B radiations, results in oxidative damage and cell death (Sharma et al., 2012). Plants counterbalance the oxidative stress via accumulation and synthesis of various antioxidant enzymes and secondary metabolites like ascorbic acid, $\beta$ carotene, flavonoids and some alkaloids which assist in neutralizing the impact of oxidative stress (Kasote et al., 2015). Secondary metabolites like flavonoids, free phenolic acids, tannins and anthocyanin's have shown tremendous potential in ROS scavenging and oxidative stress amelioration in plants (Dyduch-Siemińska et al., 2015; Pandeya et al., 2018). Flavonoids act as sunscreen to protect the inner cells of epidermis from harmful radiations, thus forming a common protective mechanism in plants (Morales et al., 2010; Petersen et al., 2010). Biosynthesis of these secondary metabolites is noticeably controlled by phenylalanine ammonia lease (PAL), and it is extensively studied enzymes in plants' responses to abiotic stress (Kim and Hwang, 2014). Increase in UV-B irradiance significantly enhances the activity of PAL which, in turn, promotes the accumulation of secondary metabolites which either directly or indirectly protect the plants from UV-B radiation (Hideg et al., 2013).

\section{Metabolic Changes Induced by Uv-B Radiations}

Plants specifically sense and precisely react to the UV-B radiations which can be observed as a modification in different morpho-physiological attributes including gene expression and secondary metabolites (Schreiner et al., 2009; Schmidt et al., 2011; Robson et al., 2015). High levels of UV-B radiations have been widely established to harm macromolecules, such as proteins, lipids and DNA, initiating with the impairment of DNA replication, photosynthesis and gene transcription (Gill et al. 2015; Liu et al. 2015; Khudyakova et al. 2019). UV-B radiations of 80-320 nm wavelength are potentially much more damaging to proteins, RNA, DNA, with increased generation of free radicals and reactive oxygen species (ROS) (Kusano et al. 2011). These harmful effects are partially aggravated by the reactive oxygen species (ROS). Plants over the years has developed different strategies to improve their growth under UV-B Stress. Secondary metabolites act as growth regulators, enzyme inhibitor, chemical signals, antioxidants and UV-B screens (Takshak and Agrawal, 2015). UV-B irradiance significantly controls the biosynthesis of secondary metabolites such as flavonoid, glucosinolate and carotenoids (Schreiner et al. 2012).

Generally, the effects of UV-B radiations on secondary metabolites are greatly dose dependent. Detrimental level of irradiance depends upon the morphological structure of the plant organs. Spherical shaped vegetables and fruits, with comparatively small surface area, require higher UV$\mathrm{B}$ irradiance to induce metabolic alterations. This effect has been demonstrated in apple (Hilal et al., 2008), lemon (Interdonato et al., 2010) and tomato (Liu et al., 2011). Physiologically young plants respond differently in contrast to the fully developed plant organs. Similarly, receptivity of plant organs against UV-B application appears to be enhanced with the increase in the surface area (Huyskens-Keil et al., 2010) along with radical physiological development (Ma et al. 2018). Dose of UV$\mathrm{B}$ application further regulates the dynamics of metabolite accumulation in plants. Secondary metabolites such as glucosinolates and carotenoids are induced at lower dose of UV-B radiations, as compared with flavonols, which are triggered by higher UV-B levels (Hagen et al., 2007; Schmidt et al. 2011). Some metabolites are rapidly unregulated, subsequent to the UV-B radiations, and other display a late response. Polyamines seem to increase quickly, while accumulation of flavonoids is comparatively slow (Jansen et al., 2008).

\section{Uv-B Radiations Induce Changes in Secondary Metabolites}

Ultraviolet radiations cause accumulation of secondary metabolites such as flavonoids, glucosinolat, terpen, alkaloid and phenolic acids which impact several physiological processes in plants. Tolerance to UV-B is associated with the induction of different signal 
transduction pathways, secondary metabolite production and DNA repair mechanisms. Besides, Mao et al. (2017) stated that the rutin, queretin and total flavonoids contents were significantly increased under the enhanced UV radiation at flowering and podding stages of soybean. Some research reports indicate that UV radiations are used to prepare plant products enriched with phytochemicals (Schreiner et al. 2009). Menghini et al. (1993) summarized that after exposure to UV-B radiations, the amount of quercetin glycosides in Brassica napus was increased.

One of the mechanisms of adaptation to UV-B radiation is the accumulation of secondary metabolites in leaf tissues. Some studies have shown that UV-B radiations induced 10 to $300 \%$ increase in some secondary metabolites of plants. One of the most effective defence mechanisms against UV-B radiations in plants is the accumulation of phenolic compounds. The epidermal layer accumulates many of the secondary metabolites such as phenolic compounds and flavonoids which protect the tissues against harmful effects of UV-B radiations. Isoprenoids are a large group of C5 - isoprene units containing compounds accumulated in plants, including carotene, xanthophylls, terpenes and others. Terpene provides protection against the deleterious effects of UV$\mathrm{B}$ radiations through absorbent compounds in plants. The accumulation of tannin, salicylate and flavonoids in the leaf, induced by UV-B radiations, was more pronounced in male, as compared with female plants. Exposure to UV-B radiation changed the composition of sterols and fatty acids and increased the abundance of antioxidants in Stereum hirsutum (Torres et al. 2016). In a study on aquatic plants such as Alternanthera sessilis (Klein et al., 2018) the highest estimated flavonoid levels were noted UV-B exposure for $8 \mathrm{~h}$, followed by a $24 \mathrm{~h}$ recovery period.

Hao et al. (2009) exhibited that UV-B in Ginkgo biloba callus enhanced nitric oxide production, activities of nitric oxide synthase and phenylalanine ammonia lyase and flavonoid content. Glycyrrhizin, a biologically active glycosidic triterpenoid of Glycyrrhiza uralensis, is accumulated in response to UV-B exposure. Glucosinolates are a sulphur-rich amino acid-derived metabolite group found only in plants against biotic and abiotic stresses. Some researchers have emphasized that the effects of UV-B on glucosinolate metabolism and the biosynthesis of genes are regulated in a different way by UV-B. An increase in the concentration of glucotropeolin of Tropaeolum majus with UV - B was observed (Gupta et al., 2017). It was found that UV-B exposure significantly increased flavonoids in Betula pendula (de la Rosa et al. 2001) and Pinus sylvestris (Lavola et al. 2003). UV-B exposure increased the flavonoid, quercitrin, the minor flavonoid, myricetin-3-galactoside chlorogenic acid contents in birch seedlings (Lavola et al. 1998). Similarly, Wulff et al. (1999) also observed an increased amount of quercetin 3-glycoside in European silver birch seedlings, exposed to high UV-B radiation. UV-B influences carotenoid contents in plants.

The flavones, flavonols, isoflavonoids, anthocyanins and phenolic acids play a protective role against prolonged exposure to high intensity solar radiations (Schreiner et al., 2012.). UV-B radiations improve the quality of medicinal plants by increasing the content of secondary metabolites (Kumari and Prasad, 2013; Pandey and Pandey-Rai, 2014).
Similarly, Ramani and Chelliah (2007) observed that mild dose of UV-B radiation is effective to increase the biosynthesis of catharanthine from Catharanthus roseus. UV-B exposure induces negative effects on tea plant growth but significantly increases the soluble phenolics and flavans (Zagoskina et al. 2003). The amount of carnosic acid, a ROS-retaining terpene, in rosemary (Rosmarinus officinalis) leaves, was doubled on exposure to UV-B radiations. UV-B exposure caused a significant increase in phenylpropanoids and terpenoids levels of Ocimum basilicum plants (Johnson et al. 1999).

UV-B radiation changed the content of amino acids, proteins and total sugars of wheat grain. These changes are indirect effects of alterations in plant vigour or reproductive capacity. No significant difference was observed in terms of coarse starch values between varieties. It has been observed that UV-B radiations decreased RNA activity and changed the expression of defence genes, leading to a change in leaf chemistry including protein, starch and soluble sugars in wheat, barley, corn, beans, tomatoes and radish leaves. Ultraviolet-B radiations can influence amino acids metabolism protein synthesis in both chloroplasts and cytoplasm. UV-B radiations are affected by the microclimate and environmental factors including temperature, precipitation, photosynthetic photon fluence, UV-A, $\mathrm{CO}_{2}$, soil fertility ( $\mathrm{Zu}$ et al., 2004). Janetta Nithia and Shanthi (2017) investigated the effect of enhanced UV$B$ radiations under field conditions and suggested that the synthesis of secondary pigments like flavonoids and anthocyanin varied among species. The accumulation of UV-B absorbent pigments is one of the effective methods of reducing the harmful effects of UV-B radiations in plants. Flavonoids can accumulate in the leaf epidermis either in the cuticle, cell wall or in the vacuole. These absorbent compounds may not be effective against UV-B radiations if contained within the mesophyll (Ravindran et al., 2010; Katerova et al., 2012). The largest UV-B absorbing compounds were observed in barley plants (Liu et al. 1995). Flavonoid content of wheat plants, exposed to UV-B and irrigation deficiency, increased with synergistically effects of both stress factors (Feng et al., 2007). Under UV-B exposure, saponarin (a flavonoid found in young green barley leaves possessing potent antioxidant activities) content was significantly increased (Kaspar et al. 2010). In a study on soybean by Mao et al. (2017), it was found that enhanced UV-B with elevated $\mathrm{O}_{3}$ damaged soybean growth mediated by changes in secondary metabolites and endogenous hormones. The duration and intensity of UV-B radiations disturb glucosinolate biosynthesis. It also influences the phenylpropanoid and flavonoid pathways, leading to changes in glucosinolate and phenolic compound concentrations (Schreiner et al., 2009).

Ultraviolet radiation has the capacity to affect a very wide array of plant metabolites including a range of antioxidants like xanthophyll's, ascorbate, tocopherol and glutathione (Topcu et al., 2015). Various polyamines such as supermini, spermidine and putrescine are known to be up regulated by the Ultraviolet radiations (Radyukina et al 2017). Soluble phenolic compounds in plants act as UV screening pigments and antioxidants as well (Nascimento et al. 2105; Wang et al.2017). Various phenolic compounds 
are favourable antioxidants and anticancer agents (Roleira et al. 2015). Similarly, synthesis of carotenoids is encouraged by the UV-B radiations via rise in phytoene synthase expression (Shen et al. 2017). Carotenogenesis is mainly managed by quality of light and controlled by UVB receptors and phytochrome (Becatti et al. 2009).

\section{Uv-B Radiation Induces Change in Phenolic Compounds}

Phenolic compounds, predominantly flavonoids are commonly known as secondary metabolites in plants that holds aromatic ring having no less than one hydroxyl groups. Approximately 800 phenolic compounds have been reported from the plants as naturally occurring substances (Tungmunnithum et al. 2018). Half of phenolic compounds are flavonoids such as glycosides, aglycone and methylated derivatives (Kumar and Pandey, 2013; Ahmed et al., 2016). Bio-synthesis and accumulation of flavonoids in chloroplasts, vacuoles and cell wall of the plants are extensively controlled by the intensity and exposure of UV-B radiations ((Tilbrook et al., 2013). Flavonoids have gain considerable attention due to its prospective health promoting advantage for humans, as they are reported as effective cardio protective (Mozaffarian et al., 2018), antioxidants (Tatullo et al., 2016), anticancer (Madunić et al., 2018), antiinflammatory (Nile et al., 2018) and anti-bacterial agent (Xie et al., 2015).

Increase in Ultraviolet-B light extensively affects the flavonoids pathways and transforms the flavonoids profile of various plants (Nascimento et al., 2015; Heinze et al., 2018; Henry-Kirk et al., 2018). Effect of Ultraviolet-B light is modified by the dose of UV-B (Xie et al., 2015), flavonoids structure along with other environmental aspects such as temperature (Virjamo et al., 2014), light quality and intensity (Fu et al., 2016) and photosynthetic photon flux density (Bilodeau et al., 2018). Idris et al. (2018) also reported that intensity, duration and wavelength of UV-B affects the accumulation of flavonoids. Generally, higher UV-B radiations tend to enhance the flavonoids accumulation in plants. UV-B improved leaf quercetin (plant flavonol) content and boosted up the total antioxidant capacity in Coriandrum sativum (Fraser et al., 2017). Noticeable accumulation of anthocyanin was observed at high light (HL) as compared to Low light (LL) in leaves tissues of P. coleoides after $4^{\text {th }}$ day of UV-B exposure (Vidovic et al., 2015). Climate change is a driving force behind the change in land and air temperature (Hannah et al., 2013). Slight change from mild to moderate temperature showed phenological modification in grapevine (Jones et al., 2005). It was reported that low temperature (LT) administration delayed the ripening phase of the grape and showed a remarkable impact on the activities of some enzymes which were involved in the bio-synthesis of flavonoids, resulting in enhanced accumulation of flavonols and anthocyanins. Contrarily, berries grown-up under high temperature (HT) displayed a great boost up in activity of peroxide, which could ultimately restrict the accumulation of flavonoids originated under these conditions (Pastore et al., 2017).

Photo synthetically active radiations (PAR) and UV-B application significantly regulates the accumulation of flavonoids and net photosynthesis of plants as given in Figure 2. Much higher generation of flavonoids was detected under PAR and UV-B application in old and young leaves (Klem et al., 2012; Morales et al., 2013). Similarly, synthesis of flavonoids, induced by the UV-B, can further be regulated by other abiotic factors such as temperature and water stress as well (Escobar-Bravo et al., 2017). Biosynthesis of flavonoid in plants is closely linked with the light intensity, histone deacetylase- 6 and photoreceptor phytochrome-B. Red/far-red (R/FR) ration and intensity of ultraviolet light are most studied aspects with respect to the effect of light quality on flavonoids concentration (Tessadori et al., 2009). Flavonoid methyltransferases and flavonoid glycoside transferases were significantly regulated through light quality via series of regulation mechanisms. flavonoid methyl derivatives showed positive correlation with far-red (FR) and near infrared (NIR) while negatively correlated with fraction of R/FR ratio and UV-A radiations. However, flavonoids and glycoside contents exhibited opposite correlation (Fu et al., 2016).

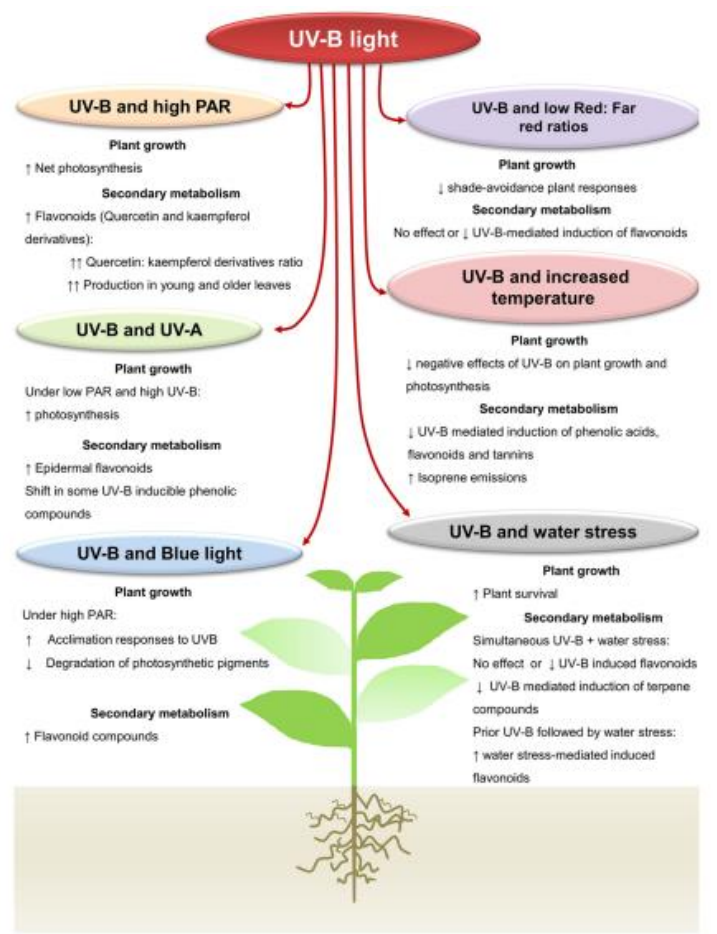

Figure 2. Interactive effects of UV-B light with other abiotic factors on plant growth and production of plant secondary metabolites

(Source: Escobar-Bravo et al., 2017).

Different studies have demonstrated that repetitive application of UV-B also regulates the plants' phenolic contents. Repeated doses of UV-B considerably increases the phenolic contents in Lactuca sativa (Lee et al., 2014). Bio synthesis of important flavonoids and phenolic compounds depends upon the threshold dose of UV-B irradiation. Strawberries (Fragaria $\times$ ananassa) under high dose of UV-B level demonstrated the much higher concentrations of anthocyanins, phenolic acids and total phenols (Ordidge er al., 2010). It is extensively studied that quercetin, along with ortho-dihydroxylated flavonoids, was significantly enhanced, whereas, kaempferol and Vitol ortho-monohydroxylated flavonoids usually remained 
unaffected by the higher doses of solar radiation especially UV-B (Winter and Rostas, 2008; Jansen and Bornman, 2012). Modest temperature and moderate dose of UV-B irradiation were also found helpful in improving phenolic contents in plants. modeate UV-B radiations $\left(0.25 \mathrm{~kJ} \mathrm{~m}^{-2}\right.$ $\mathrm{d}^{-1}-0.75 \mathrm{~kJ} \mathrm{~m}^{-2} \mathrm{~d}^{-1}$ ) successfully enhanced the level of structurally different hydroxycinnamic acid derivatives and flavonol glycosides in in kale (Brassica oleracea var. sabellica) under successive doses of UV-B radiation (Neugart et al., 2014).

\section{Uv-B Radiation Induces Change in Carotenoids}

Carotenoids, as tetraterpenoid pigments, ar a bunch of natural compounds widely found in photosynthesizing organisms like green plants, fungi, algae and bacteria as well (Sun et al., 2018). There are around 750 naturally existing carotenoids. Among them, main carotenoids such as $\alpha$-carotene, $\beta$-carotene, lutein, $\beta$-cryptoxanthin, astaxanthin, lycopene, fucoxanthin and zeaxanthin are well documented. Carotenoids play exceptional role in photo protection and photosynthesis of plants (Hashimoto et al., 2016). Carotenoids works as necessary pigment in process of light harvesting. Carotenoid plays a Vitol role in scavenging of reactive oxygen species (ROS) produced under UV-B radiation stress and also safeguard the chlorophyll contents from photo oxidation (Shen et al., 2018). Excessive production of ROS may otherwise irreversibly damage the DNA, proteins and lipids eventually leading to cell death. White and Jahnke (2002) reported that $\beta$-carotene successfully protected the cells of Dunaliella $s p$ by scavenging the free radicals and ROS produced as a result of oxidative stress induced by UV-A and UV-B radiations. Polyene backbone is the core structural component in carotenoids as it contains sequence of conjugated bonds $(\mathrm{C}=\mathrm{C}$ bonds). This special feature is predominantly accountable for pigmentation properties and potential of these compounds to effectively interact with ROS and other free radicals, thus act as active antioxidants (Andrew and Lowe, 2018). Increased UV-B irradiance $\left(+9.75 \mathrm{~mW} \mathrm{~cm}^{-2}+20.76 \mathrm{~mW} \mathrm{~cm}^{-2}\right)$ encourages the enhanced accumulation of lutein (carotenoid), which further improves the total antioxidant capacity (TAC) of antioxidant system to prevent the photo oxidative damage in tobacco plant (Shen et al., 2017).

Temperature and light intensity are the main environmental aspects affecting the growth and development of plants. Slight change in intensity, duration and range of light can cause cellular damage and eventually leads to the death of plant. Different plants have adapted numerous protective mechanisms that make help them survive under unfavourable conditions of light and temperature stress (Szymańska e t al. 2017). Crucial part of antioxidant system usually operates in chloroplast where carotenoids exist (Sun et al., 2018). Carotenoids pathways at transcript level appear to be associated with stress response e.g. light stress. High intensity of light increases the steady state of carcinogenic enzymes such as phytoene desaturase (PDS) and phytoene synthase (PSY). Maximum steady-state of $\beta$-LCY at mRNA levels was observed when exposed to maximum light intensity of $5001 \mathrm{~mol} \mathrm{~m}^{-2} \mathrm{~s}^{-1}$. Similarly, bcarotene content accumulation at cellular level was twice at maximum light intensity of (500 $\left.1 \mathrm{~mol} \mathrm{~m}^{-2} \mathrm{~s}^{-1}\right)$ as compared to the value attained at low light $\left(45 \mathrm{lmol} \mathrm{m} \mathrm{m}^{-2} \mathrm{~s}^{-1}\right)$ conditions in Dunaliella salina (Ramos et al.,2008). Improved accumulation of antheraxanthin and zeaxanthin was observed under high intensity light in Chlamydomonas reinhardtii (Couso et al. 2012). Zeaxanthin fractions were also enhanced in cells of Dunaliella salina with the increase in the light irradiance (Fu et al., 2013). Light intensity significantly affects the biomass and lutein productivity in Chlamydomonas sp. The highest lutein productivity of $5.08 \mathrm{mg} / \mathrm{L} / \mathrm{d}$ was attained at high light irradiation of $625 \mu \mathrm{mol} / \mathrm{m} 2 / \mathrm{s}$ (Ma., 2019).

Temperature affects the quality and yield of the crops by altering their important biochemical and physiological processes (Wang et al. 2016; Sunoj et al. 2016; Yang et al. 2016; $\mathrm{Xu}$ et al. 2016). Environmental temperature significantly affects the carotenogenesis as well. Accumulation of carotenoids increases with the increase in the temperature. Threefold increase in the astaxanthin was observed in Haematococcus pluvialis with increase in temperature from 20 to $30^{\circ} \mathrm{C}$. High temperature induces higher accumulation of carotenoids contents (Juneja et al. 2013). Significant reduction in carotenoids contents was observed in Pisum sativum L. (Juozaityte et al., 2008), Phyllanthus amarus L (Indrajith and Ravindran, 2009) and Dolichos lablab (Singh et al., 2011) as a result of UV-B stress. Oxidative stress destroys the carotenoids contents at much higher pace than their capability of scavenging the ROS, which results in reduced ability to mitigate the UVB stress. Therefore, a complex relationship exists between carotenoids and ROS under UV-B stress.

\section{Uv-B Radiation Induces Change in Glucosinolates}

Glucosinolates (GSL) are well known secondary metabolites having sulfur- and nitrogen-compounds. They are well known for keeping auxin homeostasis in plants, and preventing cancer in human. Glucosinolates are classified in three categories; (1) aliphatic glucosinolate derived from leucine, alanine and valine, (2) indolic glucosinolate derived from tryptophan and (3) benzoic glucosinolate derived from tyrosine and phenylalanine (Kliebenstein et al., 2005). Around 130 Glucosinolates are identified so far, and they belong to family Brassicaceae (Baskar et al., 2012). Production and accumulation of phenolic compounds and flavanoids against exposure to UV-B radiation is well documented. Whereas, effects of UV-B irradiance on production and accumulation of glucosinolates has gained little and no consideration in past. Reports on the outcomes of UV-B radiations on preharvest and postharvest lucosinolate contents are scarce in the previous literature. UV-B irradiance $\left(5.5 \mathrm{~kJ} \mathrm{~m}^{-2}\right)$ significantly affected the expression of gene responsible for the synthesis of indolyl GLS in A. thaliana (Demkura and Ballaré, 2012). UV-B irradiation $\left(20 \mathrm{~kJ} \mathrm{~m}^{-2} \mathrm{~d}^{-1}\right)$ also influenced the indolyl GLS, total aliphatic and total GLS in Brassica oleracea L. var. italic (Rybarczyk-Plonska et al., 2016). An increase in total GLS was observed in mustard, nasturtium (Reifenrath and Mueller, 2007) and canola (Moghadam et al., 2012) under UV-B treatment. Even low level exposure of UV-B (0.3 to $\left.0.6 \mathrm{~kJ} \mathrm{~m}^{-2} \mathrm{~d}^{-1}\right)$ considerably enhanced the total glucosinolate contents in broccoli sprouts (Pérez-Balibrea et al., 2010). Recently, Moreira-Rodríguez et al. (2017) also reported an extensive increase in total glucosinolate content $(\sim 148 \%)$ of 
young broccoli sprouts under UV-B $\left(7.16 \mathrm{~W} / \mathrm{m}^{-2}\right)$ treatment. While in contrast, Wang et al. (2012) reported a significant decline in total glucosinolate in A. thaliana on continuous exposure to UV-B for 12 hours.

\section{Future outlook}

This review revealed that UV-B radiations affected the morphologic and anatomic characteristics of leaf. It is a fact that the most important mechanisms of adaptation to UV-B radiation are the accumulation of secondary metabolites in leaf tissues. Especially, flavonoids protected DNA from UV-induced DNA damage can accumulate in the leaf epidermis, either in the cuticle, cell wall or in the vacuole as a clear example of this mechanism. External moderate dose of UV-B irradiation together with modest temperature were also found helpful in improving phenolic contents in plants. Moreover, carotenoid plays a vital role in scavenging of reactive oxygen species (ROS) produced under UV-B radiations stress and also safeguard the chlorophyll contents from photooxidation. Similarly, increased UV-B irradiance stimulated the accumulation of carotenoid such as lutein, which further improves the total antioxidant capacity (TAC) of antioxidant system to prevent the photooxidative damage in plant. As a result, review explained that UV radiations altered many aspects of plant growth and metabolism, including the development of defence compounds and structures.

\section{References}

Ahmed SI, Hayat MQ, Tahir M, Mansoor Q, Ismail M, Keck K, Bates RB. 2016. Pharmacologically active flavonoids from the anticancer, antioxidant and antimicrobial extracts of Cassia angustifolia Vahl. BMC Complement. Altern. Med. 16: 460.

Baskar V, Gururani MA, Yu JW, Park SW. 2012. Engineering glucosinolates in plants: Current Knowledge and potential uses. Appl. Bioch. Biotech. 168: 1694-1717.

Becatti E, Petroni K, Giuntini D, Castagna A, Calvenzani V, Serra G, Mensuali-Sodi A, Tonelli C, Ranieri A. 2009. Solar UV-B radiation influences carotenoid accumulation of tomato fruit through both ethylene-dependent and -independent mechanisms. J. Agric. Food Chem. 57: 10979-10989.

Bilodeau SE, Wu B-S, Rufyikiri A-S, MacPherson S, Lefsrud M. 2019. An Update on Plant Photobiology and Implications for Cannabis Production. Front. Plant Sci. 29 March 2019 https://doi.org/10.3389/fpls.2019.00296.

Binkert M, Kozma-Bognar L, Terecskei K, De Veylder L, Nagy F, Ulm R. 2014. UV-B-responsive association of the Arabidopsis bZIP transcription factor ELONGATED HYPOCOTYL5 with target genes, including its own promoter. Plant Cell. 26:4200- 4213.

Brosché M, Strid A. 2000. Ultraviolet-B radiation causes tendril coiling in Pisum sativum. Plant and Cell Physiology. 41: 1077-1079.

Christie JM, Arvai AS, Baxter KJ, Heilmann M, Pratt AJ, O'Hara A, Kelly SM, Hothorn M, Smith BO, Hitomi K, Jenkins KI, Getzoff ED. 2012. Plant UVR8 photoreceptor senses UV-B by tryptophan-mediated disruption of cross-dimer salt bridges. Science 335: 1492-1496.

Couso I, Vila M, Vigara J, Cordero B, Vargas M, Rodríguez H, León R. 2012. Synthesis of carotenoids and regulation of the carotenoid biosynthesis pathway in response to high light stress in the unicellular microalga Chlamydomonas reinhardtii. Europ J Phycol., 47:223-232. de la Rosa TM, Julkunen-Tiitto R, Lehto T, Aphalo PJ. 2001. Secondary metabolites and nutrient concentrations in silver birch seedlings under five levels of daily UV-B exposure and two relative nutrient addition rates. New Phytologist. 150: 121-131.

Delgardo-Vargas F, Jime'nez AR, Paredes-Lo'pez O. 2000. Natural pigments: carotenoids, anthocyanins and betalains. Characteristics, biosynthesis, processing, and stability. Critical Reviews in Food Science and Nutrition. 40: 173-289.

Demkura PV, Ballare CL. 2012. UVR8 mediates UV-B-induced Arabidopsis defense responses against Botrytis cinerea by controlling sinapate accumulation. Mol. Plant. 5:116-126.

Dietz KJ, Turkan I, Krieger-Liszkay A. 2016. Redox- and reactive oxygen species-dependent signaling into and out of the photosynthesizing chloroplast. Plant Physiol. 171: 15411550 .

Dyduch-Siemińska M, Najda A, Dyduch J, Gantner M, Klimek K. 2015. The Content of Secondary Metabolites and Antioxidant Activity of Wild Strawberry Fruit (Fragaria vesca L.). J Anal Methods Chem., 831238.

Escobar-Bravo R, Klinkhamer PGL, Leiss KA. 2017. Interactive effects of UV-B light with abiotic factors on plant growth and chemistry, and their consequences for defense against arthropod herbivores. Front Plant Sci. 8:14

Fasano R, Gonzalez N, Tosco A, Dal Piaz F, Docimo T, Serrano R, Grillo S, Leone A. 2014. Inze D: Role of Arabidopsis UV RESISTANCE LOCUS 8 in plant growth reduction under osmotic stress and low levels of UV-B. Mol. Plant. 7:773791.

Favory JJ, Stec A, Gruber H, Rizzini L, Oravecz A, Funk M, Albert A, Cloix C, Jenkins GI, Oakeley EJ, Seidlitz HK, Nagy F, Ulm R. 2009. Interaction of COP1 and UVR8 regulates UV-B-induced photomorphogenesis and stress acclimation in Arabidopsis. EMBO J. 28:591-601.

Favory JJ, Stec A, Gruber H, Rizzini L, Oravecz A, Funk M, Albert A, Cloix C, Jenkins GI, Oakeley EJ, Seidlitz HK, Nagy F, Ulm R. 2009. Interaction of COP1 and UVR8 regulates UV-B-induced photomorphogenesis and stress acclimation in Arabidopsis. EMBO J. 28: 591-601.

Feng H, Li S, Xue L, An L, Wang X. 2007. The interactive effects of enhanced UVB radiation and soil drought on spring wheat, South Afr. J. Bot. 73: 429-434

Fierro AC, Leroux O, De Coninck B, Cammue BP, Marchal K, Prinsen E, Van Der Straeten D, Vandenbussche F. 2015. Ultraviolet-B radiation stimulates downward leaf curling in Arabidopsis thaliana. Plant Physiol. Biochem. 93:9-17.

Fraser DP, Sharma A, Fletcher T, Budge S, Moncrieff C, Dodd AN, Franklin KA. 2017. UV-B antagonises shade avoidance and increases levels of the flavonoid quercetin in coriander (Coriandrum sativum). Sci Rep. 7: 17758.

Frohnmeyer H, Staiger D. 2003. Ultraviolet-B radiation-mediated responses in plants. Balancing damage and protection. Plant Physiol. 133:1420-28

Fu W, Guðmundsson Ó, Paglia G, Herjólfsson G, Andrésson Ós, Palsson BØ, Brynjólfsson S. 2013. Enhancement of carotenoid biosynthesis in the green microalga Dunaliella salina with light-emitting diodes and adaptive laboratory evolution. Appl. Microbiol. Biotechnol. 97(6):2395-2403.

Gao W, Zheng Y, Slusser JR, Heisler GM. 2003. Impact of enhanced ultravioletB irradiance on cotton growth, development, yield and qualities under field conditions. Agric. For. Meteor. 120: 241-248.

Gill SS, Anjum NA, Gill R, Tuteja N. 2015. DNA damage and repair in plants under ultraviolet and ionizing radiations. Sci. World J. 250158. doi: 10.1155/2015/250158.

Gonzalez Besteiro MA, Bartels S, Albert A, Ulm R. 2011. Arabidopsis MAP kinase phosphatase 1 and its target MAP kinases 3 and 6 antagonistically determine UV-B stress tolerance, independent of the UVR8 photoreceptor pathway. Plant J. 68:727-737. 
Gonzalez R, Mepsted R, Wellburn AR, Paul ND. 1998. Nonphotosynthetic mechanisms of growth reduction in pea (Pisum sativum L.) exposed to UV-B radiation. Plant, Cell \& Environment 21: 23-32.

Gruber H, Heijde M, Heller W, Albert A, Seidlitz HK, Ulm R. 2010. Negative feedback regulation of UV-B-induced photomorphogenesis and stress acclimation in Arabidopsis. Proc. Natl. Acad. Sci. U.S.A. 107:20132-20137.

Gu XD, Sun MY, Zhang L, Fu HW, Cui L, Chen RZ, Zhang DW, Tian JK. 2010. UV-B induced changes in the secondary metabolites of Morus alba L. Leaves. Molecules. 15: 29802993.

Gupta SK, Sharma M, Deeba F, Pandey V. 2017. Plant response: UV-B avoidance mechanisms. In Singh VP, Singh S, Prasad SM, Pariha P. (eds). UV-B Radiation: From Environmental Stressor to Regulator of Plant Growth. New York: John Wiley \& Sons Ltd., 217-58.

Hagen SF, Borge GIA, Bengtsson GB, Bilger W, Berge A, Haffner K, Solhaug KA. 2007. Phenolic contents and other health and sensory related properties of apple fruit (Malus domestica Borkh., cv. Aroma): Effect of postharvest UV-B irradiation. Postharvest Biol. Technol. 45: 1-10.

Hannah L, Roehrdanz PR, Ikegami M, Shepard AV, Shaw MR, Tabor G, Zhi L, Marquet PA, Hijmans RJ. 2013. Climate change, wine, and conservation. Proc. Natl. Acad. Sci. U.S.A. 110, 6907-6912.

Hao G, Du X, Zhao F, Shi R, Wang J. 2009. Role of nitric oxide in UV-B-induced activation of PAL and stimulation of flavonoid biosynthesis in Ginkgo biloba callus. Plant Cell Tiss Organ Cult. 97: 175-185.

Hashimoto H, Uragami C, Cogdell RJ. 2016. Carotenoids and photosynthesis. Subcell. Biochem. 79:111-139.

Hayes S, Sharma A, Fraser DP, Trevisan M, Cragg-Barber CK, Tavridou E, Fankhauser C, Jenkins GI, Franklin KA. 2017. UV-B perceived by the UVR8 photoreceptor inhibits plant thermomorphogenesis. Curr. Biol. 27:120-127.

Hayes S, Velanis CN, Jenkins GI, Franklin KA. 2014. UV-B detected by the UVR8 photoreceptor antagonizes auxin signaling and plant shade avoidance. Proc. Natl. Acad. Sci. $111: 11894-11899$.

Heijde M, Ulm R. 2012. UV-B photoreceptor-mediated signalling in plants. Trends Plant Sci. 17:230-37.

Heijde M, Ulm R. 2013. Reversion of the Arabidopsis UV-B photoreceptor UVR8 to the homodimeric ground state. Proc. Natl. Acad. Sci. 110:1113-1118.

Heinze M, Hanschen FS, Wiesner-Reinhold M, Baldermann S, Grafe J, Schreiner M, Neugart S. 2018. Effects of developmental stages and reduced uvb and low uv conditions on plant secondary metabolite profiles in Pak Choi (Brassica rapa subsp chinensis). J. Agric. Food Chem. 66: 1678-1692.

Henry-Kirk RA, Plunkett B, Hall M, McGhie T, Allan AC, Wargent JJ, Espley RV. 2018. Solar UV light regulates flavonoid metabolism in apple (Malus $\times$ domestica). Plant Cell Environ. 41(3):675-688

Herms DA, Mattson WJ. 1992. The dilemma of plants: to grow or defend. Quarterly Review of Biology. 67: 283-335.

Hideg É, Jansen MAK, Strid Å. 2013. UVB exposure, ROS, and stress: inseparable companions or loosely linked associates? Trends Plant Sci. 18: 107-115.

Hidema J, Kumagai T. 2006. Sensitivity of rice to ultraviolet-B radiation. Annal Bot. 97:933-42.

Hilal M, Rodríguez-Montelongo L, Rosa M, Gallardo M, González JA, Interdonato R, Rapisarda VA, Prado FE. 2008. Solar and supplemental UV-B radiation effects in lemon peel UV-B-absorbing compound content-seasonal variations. Photochem. Photobiol. 84:1480-1486.

Höll J, Lindner S, Walter H, Joshi D, Poschet G, Pfleger S, Ziegler T, Hell R, Bogs J, Rausch T. 2019. Impact of pulsed UV-B stress exposure on plant performance: How recovery periods stimulate secondary metabolism while reducing adaptive growth attenuation. Plant Cell Environ. 42(3):801-814.
Huang S, Van Aken O, Schwarzlander M, Belt K, Millar AH. 2016. The roles of mitochondrial reactive oxygen species in cellular signaling and stress response in plants. Plant Physiol. 171:1551-1559.

Huyskens-Keil S, Schreiner M, Krumbein A, Reichmuth C, Janata E, Ulrichs C. 2010. UV-B and gamma irradiation as physical elicitors to promote phytochemicals in Brassica sprouts. Acta Hort. 858: 37-41.

Indrajith A, Ravindran KC. 2009. Antioxidant potential of Indian medicinal plant on Phyllanthus amarus L. under supplementary UV-B radiation. Recent Res. Sci. Technol. 1: 34-42.

Interdonato R, Rosa M, Nieva CB, Gonzalez JA, Hilal M, Prado F.E. 2010. Effects of low UV-B doses on the accumulation of UV-B absorbing compounds and total phenolics and carbohydrate metabolism in the peel of harvested lemons. Environ. Exp. Bot. 70: 204-211.

Janetta Nithia SM, Shanthi N. 2017. Effect of enhanced solar UVB (280-320nm) radiation on secondary pigment synthesis in some plants. International Journal of Environmental \& Agriculture Research. 3 (1):111-115

Jansen MAK, Bornman JF. 2012. UV-B radiation: from generic stressor to specific regulator. Physiol. Plantarum. 145: 501504.

Jansen MAK, Hectors K, O'Brien NM, Guisez Y, Potters G. 2008. Plant stress and human health: Do human consumer benefit from UV-B acclimated crops? Plant Sci. 175: 449458.

Johnson CB, Kirby J, Naxakis G, Pearson S. 1999. Substantial UV-B-mediated induction of essential oils in sweet basil (Ocimum basilicum L.). Phytochemistry, 51: 507-510.

Jones GV, White MA, Cooper OR, Storchmann K. 2005. Climate change and global wine quality. Clim. Change 73: 319-343.

Juozaitytė R, Ramaškevičienė A, Sliesaravičius A, Burbulis N, Kuprienė R, Liakas V, Blinstrubienè A. 2008. Effects of UVB radiation on photosynthesis pigment system and growth of pea (Pisum sativum L.). Sci Works Lithuanian Inst. Hortic. Lithuanian Univ. Agric. 27: 179-186.

Kakani VG, Reddy KR, Zhao D, Mohammed AR. 2003 b. Ultraviolet-B radiation effects on cotton (Gossypium hirsutum L.) morphology and anatomy. Ann. Bot. 817-826.

Kakani VG, Reddy KR, Zhao D, Sailaja K. 2003 a. Field crop response to ultraviolet-B radiation: a review. Agric Forest Meteorol. 120:191-218

Kasote DM, Katyare SS, Hegde MV, Bae H. 2015. Significance of antioxidant potential of plants and its relevance to therapeutic applications. Int. J. Biol. Sci. 11:982-991.

Kaspar S, Matros A, Mock H-P. 2010. Proteome and flavonoid analysis reveals distinct responses of epidermal tissue and whole leaves upon UV-B radiation of barley (Hordeum vulgare L.) seedlings. Journal of Proteome Research. 9(5): 2402-2411.

Kataria S, Jajoo A, Guruprasad KN. 2014. Impact of increasing ultraviolet-B (UV-B) radiation on photosynthetic processes. J Photochem Photobiol B Bio.1 137:55-66.

Katerova Z, Todorova D, Tasheva K, Sergiev I. 2012. Influence of ultraviolet radiation on plant secondary metabolite production. Genetics and Plant Physiology. 2(3-4): 113-144.

Khudyakova AY, Kreslavski VD, Shmarev AN, Lyubimov VY, Shirshikova GN, Pashkovskiy PP, Kuznetsov VV, Allakhverdiev SI. 2019 Impact of UV-B radiation on the photosystem II activity, pro-/antioxidant balance and expression of light-activated genes in Arabidopsis thaliana hy4 mutants grown under light of different spectral composition. Journal of Photochemistry and Photobiology B: Biology. 194: 14-20.

Kim DS, Hwang BK. 2014. An important role of the pepper phenylalanine ammonia-lyase gene (PAL1) in salicylic aciddependent signalling of the defence response to microbial pathogens. J Exp Bot. 65(9): 2295-2306. 
Klein FRS, Reis A, Kleinowski AM, Telles RT, do Amarante L, Peters JA, Braga EJB. 2018. UV-B radiation as an elicitor of secondary metabolite production in plants of the genus Alternanthera. Acta Bot. Bras. 32 (4): 615-623.

Klem K, Ač A, Holub P, Kováč D, Špunda V, Robson TM, Urban O. 2012. Interactive effects of PAR and UV radiation on the physiology, morphology and leaf optical properties of two barley varieties. Environ. Exp. Bot. 75:52-64.

Kliebenstein DJ, Kroymann J, Mitchell-Olds T. 2005. Current Opinion in Plant Biology. 8: 264-271.

Koti S, Reddy KR, Reddy VR, Kakani VG, Zhao D. 2005. Interactive effects of carbon dioxide, temperature, and ultraviolet-B radiation on soybean (Glycine max L.) flower 251 and pollen morphology, pollen production, germination, and tube lengths. Journal of Experimental Botany. 56: 725736

Kumar S, Pandey AK. 2013. Chemistry and biological activities of flavonoids: An overview. Sci. World J. 162750.

Kumari R, Prasad MNV. 2013. Medicinal Plant Active Compounds Produced by UV-B Exposure. Sustainable Agriculture Reviews. 12:225-254. doi: 10.1007/978-94-0075961-9_8

Kusano M, Tohge T, Fukushima A, Kobayashi M, Hayashi N, Otsuki H, Kondou Y, Goto H, Kawashima M, Matsuda F, Niida R, Matsui M, Saito K, Fernie AR. 2011. Metabolomics reveals comprehensive reprogramming involving two independent metabolic responses of Arabidopsis to UV-B light. Plant J. 67:354-369.

Lake, JA, Field KJ, Davey MP, Beerling DJ, Lomax BH. 2009. Metabolomic and physiological responses reveal multiphasic acclimation of Arabidopsis thaliana to chronic UV radiation. Plant, Cell Environ. 32: 1377-1389.

Lavola A, Aphalo PJ, Lahti M, Julkunen- Tiitto R. 2003. Nutrient availability and the effect of increasing UV-B radiation on secondary plant compounds in Scots .pine. Environm Exp Botany, 49: 49-60.

Lavola A, Julkunen-T11tto R, Aphalo P, De La Rosa T, Lehto T. 1998. The effect of UV-B radiation on UV-absorbing secondary metabolites in birch seedlings grown under simulated forest soil. New Phytol.137:617-621.

Lee MJ, Son JE, Oh MM. 2014. Growth and phenolic compounds of Lactuca sativa L. grown in a closed-type plant production system with UV-A, -B, or -C lamp. Journal of the Science of Food and Agriculture. 94, 197-204.

Liu C, Han X, Cai L, Lu X, Ying T, Jiang Z. 2011. Postharvest UV-B irradiation maintains sensory qualities and enhances antioxidant capacity in tomato fruit during storage. Postharvest Biol. Technol. 59: 232-237.

Liu L, Dennis C, Gitz III, McClure JW. 1995. Effects of UV-B on flavonoids, ferulic acid, growth and photosynthesis in barley primary leaves. Physiol Plant. 93:734-8

Liu L, Gregan S, Jordan WC. 2015. From UVR8 to flavonol synthase: UV- induced gene expression in Sauvignon blanc grape berry. Plant Cell Environment. 38: 905-919.

Ma M, Wang P, Yang R, Gu Z. 2018. Effects of UV-B Radiation on the Isoflavone Accumulation and Physiologicalbiochemical Changes of Soybean during Germination. Food Chemistry. 250:259-267.

Madunić J, Madunić IV, Gajski G, Popić J, Garaj-Vrhovac V. 2018. Apigenin: A dietary flavonoid with diverse anticancer properties. Cancer Letters. 413:11-22.

Mao B, Yin H, Wang Y, Zhao TH, Tian RR, Wang W, Jia-Shu Y. 2017. Combined effects of $\mathrm{O} 3$ and UV radiation on secondary metabolites and endogenous hormones of soybean leaves. PLoS ONE 12(8): e0183147. https://doi.org/10.1371/journal.pone.0183147

Mark U, Tevini M. 1996. Combination effects of UV-B radiation and temperature on sunflower (Helianthus annuus L., cv. Polstar) and maize (Zea mays L., cv. Zenit 2000) seedlings. Journal of Plant Physiology. 148: 49-56
Matthew Robson T, Klem K, Urban O, Jansen MAK. 2015. Reinterpreting plant morphological responses to UV-B radiation. Plant, Cell and Environment. 38: 856-866.

Mazza CA, Ballare CL. 2015. Photoreceptors UVR8 and phytochrome B cooperate to optimize plant growth and defense in patchy canopies. New Phytol. 207:4-9.

Menghini A, Capuccella M, Mercati V, Mancini L, Burata M. 1993. Flavonoids contents in Passiflora spp. Pharmacol. Res. Commun. 27:13-14

Mewis M, Schreiner N, Nhi C, Krumbein A, Ulrichs C, Lohse M, Zrenner R.2012. UV-B irradiation changes specifically the secondary metabolite Profile in Broccoli sprouts: Induced signaling overlaps with defense response to biotic stressors. Plant Cell Physiol. 53:1546-1560

Morales LO, Brosché M, Vainonen J, Jenkins GI, Wargent JJ, Sipari N, Strid Å, Lindfords AV, Tegelberg R, Aphalo PJ. 2013. Multiple roles for UV RESISTANCE LOCUS8 in regulating gene expression and metabolite accumulation in Arabidopsis under solar ultraviolet radiation. Plant Physiol. 161: 744-759.

Morales LO, Tegelberg R, Brosché M, Keinänen M, Lindfors A, Aphalo PJ. 2010. Effects of solar UV-A and UV-B radiation on gene expression and phenolic accumulation in Betula pendula leaves. Tree Physiol. 30:923-934.

Moreira-Rodríguez M, Nair V, Benavides J, Cisneros-Zevallos L, Jacobo-Velázquez DA. 2017. UVA, UVB Light, and Methyl Jasmonate, Alone or Combined, Redirect the Biosynthesis of Glucosinolates, Phenolics, Carotenoids, and Chlorophylls in Broccoli Sprouts. Int J Mol Sci. 4:18(11).

Mozaffarian D, Wu JHY. 2018. Flavonoids, dairy foods, and cardiovascular and metabolic health: a review of emerging biologic pathways. Circ Res. 122(2):369-84.

Nascimento LBDS, Leal-Costa MV, Menezes EA, Lopes VR, Muzitano MF, Costa SS, Tavares ES. 2015. Ultraviolet-B radiation effects on phenolic profile and flavonoid content of Kalanchoe pinnata. J Photochem Photobiol B Biol. 148:7381.

Neugart S, Fiol M, Schreiner M, Rohn S, Zrenner R, Kroh LW, Krumbein A. 2014. Interaction of moderate UV-B exposure and temperature on the formation of structurally different flvonol glycosides and hydroxycinnamic acid derivatives in kale (Brassica oleracea var. sabellica). Journal of Agricultural and Food Chemistry. 62: 4054-4062.

Neugart S, Schreiner M. 2018. UVB and UVA as eustressors in horticultural and agricultural crops, Sci. Hortic. 234: 370-381

Nile SH, Keum YS, Nile AS, Jalde SS, Patel RV. 2018. Antioxidant, anti-inflammatory, and enzyme inhibitory activity of natural plant flavonoids and their synthesized derivatives. J Biochem Mol Toxicol. 32(1):e22002.

Nithia SMJ, Shanthi N, Kulandaivelu G. 2005. Different responses to UV-B enhanced solar radiation in radish and carrot. Photosynthetica. 43:307-311.

Ordidge M, Garcia-Macias P, Battey NH, Gordon MH, Hadley P, John P, Lovegrove JA, Vysini E, Wagstaffe A. 2010. Phenolic contents of lettuce, strawberry, raspberry, and blueberry crops cultivated under plastic films varying in ultraviolet transparency. Food Chem. 119:1224-1227

Pandey N, Pandey-Rai S. 2014. Short-term UV-B radiationmediated transcriptional responses and altered secondary metabolism of in vitro propagated plantlets of Artemisia annua L. Plant Cell Tiss Organ Cult.116:371-385

Pandeya A, Rayamajhi S, Pokhrel P, Giri B. 2018. Evaluation of secondary metabolites, antioxidant activity, and color parameters of Nepali wines. Food and nutrition. 6 (8): 22522263.

Pastore C, Allegro G, Valentini G, Muzzi E, Filippetti I. 2017. Anthocyanin and favonol composition response to veraison leaf removal on Cabernet Sauvignon, Nero d'Avola, Raboso Piave and Sangiovese Vitis vinifera L. cultivars. Sci. Hortic. 218: $147-155$. 
Pérez-Balibrea S, Moreno DA, García-Viguera C. 2010. Glucosinolates in broccoli sprouts (Brassica oleracea var. italica) as conditioned by sulphate supply during germination. J. Food Sci. 75: 673-677.

Petersen M, Hans J, Matern U. 2010. "Biosynthesis of phenylpropanoids and related compounds," in Annual Plant Reviews: Biochemistry of Plant Secondary Metabolism, Vol. 40, ed. M. Wink (Hoboken, NJ: Wiley-Blackwell). 182-257.

Quan J, Song S, Abdulrashid K, Chai Y, Yue M, Liu X. 2018. Separate and combined response to UV-B radiation and jasmonic acid on photosynthesis and growth characteristics of Scutellaria baicalensis. Int. J. Mol. Sci. 19:1194

Radyukina YV, Mapelli IS, Mikheeva LE, Karbysheva EA. 2017. Vestnik Moskovskogo Universiteta, Seriya 16: Biologiya. 72(3): 179-183.

Ramani S, Chelliah J. 2007. UV-B-induced signalling events leading to enhanced-production of catharanthine in Catharanthus roseus cell suspension cultures. BMC Plant Biol. 7:61-77. doi:10.1186/1471-2229-7-61

Ramani S, Chelliah J. 2008. Enhanced catharanthine and vindoline production in suspension cultures of Catharanthus roseus by ultraviolet-B light. J Mol Signal. 3: 9-14.

Ravindran KC, Indrajith A, Pratheesh PV, Sanjiviraja K, Balakrishnan V. 2010. Effect of ultraviolet-B radiation on biochemical and antioxidant defence system in Indigofera tinctoria L. seedlings. Int. J. Eng. Tech. 2 (5): 226-232.

Reifenrath K, Mueller C. 2007. Species-specifi and leaf-age dependent effects of ultraviolet radiation on two Brassicaceae. Phytochemistry. 68: 875-885.

Rizzini L, Favory JJ, Cloix C, Faggionato D, O'Hara A, Kaiserli E, Baumeister R, Schafer E, Nagy F, Jenkins GI, Ulm R. 2011. Perception of UV-B by the Arabidopsis UVR8 protein. Science. 332:103-106.

Roleira FMF, Tavares-da-Silva EJ, Varela CL, Costa SC, Silva T, Garrido J, Borges F. 2015. Plant derived and dietary phenolic antioxidants: anticancer properties, Food Chemistry. 183: 235-258.

Ruijuan Ma, Xurui Zhao, Youping Xie, Shih-Hsin Hoa, Jianfeng Che. 2019. Enhancing lutein productivity of Chlamydomonas sp. via high-intensity light exposure with corresponding carotenogenic genes expression profiles. Bioresource Technology. 275:416-420.

Rybarczyk-Plonskaa A, Hagen SF, Borge GIA, Bengtsson GB, Hansena MK, Wold AB. 2016. Glucosinolates in broccoli (Brassica oleracea L. var. italica) as affected by postharvest temperature and radiation treatments. Postharvest Biology and Technology 116:16-25.

Schmidt S, Zietz M, Schreiner M, Rohn S, Kroh LW, Krumbein A. 2011. Influence of UV-B on flavonol aglycones and main flavonol glycosides in kale (Brassica oleracea var. sabellica). In: Proceedings UV4growth, COST Action FA0906, 7-9 February, Szeged, Hungary, p. 27.

Schreiner M, Krumbein A, Mewis I, Ulrichs C, HuyskensKeil S. 2009. Short-term and moderate UV-B radiation efects on secondary plant metabolism in different organs of nasturtium (Tropaeolum majus L.). Innovative Food Science \& Emerging Technologies. 10: 93-96.

Schreiner M, Mewis I, Huyskens-Keil S, Jansen MAK, Zrenner R, Winkler JB, O'Brien N, Krumbein A. 2012. UV-BInduced Secondary Plant Metabolites - Potential Benefits for Plant and Human Health, Critical Reviews in Plant Sciences. 31:3: 229-240.

Schreiner M, Mewis I, Huyskens-Keil S, Jansen MAK, Zrenner R, Winkler J.B. O'Brien N, Krumbein A. 2012. UV-BInduced Secondary Plant Metabolites Potential Benefits for Plant and Human Health, Critical Reviews in Plant Sciences. 31(3): 229-240

Schreiner M. 2009. Die Rolle des Verbrauchers in der Wertschopfungskette." In: Status quo und Perspektiven des deutschen Gartenbaus, pp. 99-109. Dirksmeyer, W., Ed., Landbauforschung vti, Sonderheft 330, Braunschweig, Germany.
Sharma P, Jha AB, Dubey RS, Pessarakli M. 2012. Reactive oxygen species, oxidative damage, and antioxidative defense mechanism in plants under stressful conditions. J. Bot. 2012:217037.

Sharma R. 2001. Impact of solar UV-B on tropical ecosystems and agriculture. Case study: effect of UV-B on rice. Proc. SEAWIT98 SEAWPIT2000. 1: 92-101.

Sharma S, Chatterjee S, Kataria S, Joshi J, Datta S, Vairale MG, Veer V. 2017. A review of stress and responses of plants to UV-B radiation. In: Singh VP, Singh S, Prasad MS, Parihar P (eds) UV-B radiation: from environmental stressor to regulator of plant growth. Wiley-Blackwell, New York, pp $75-99$.

Shen J, Jiang C, Yan Y, Liu B, Zu C. 2017. Effect of increased UV-B radiation on carotenoid accumulation and total antioxidant capacity in tobacco (Nicotiana tabacum L.) leaves. Genet Mol Res. 8:16(1).

Shen Y, Li J, Gu R, Yue L, Wang H, Zhan X, Xing B. 2018. Carotenoid and superoxide dismutase are the most effective antioxidants participating in ROS scavenging in phenanthrene accumulated wheat leaf. Chemosphere. 197:513-525.

Singh R, Singh S, Tripathi R, Agrawal SB. 2011. Supplemental UV-B radiation induced changes in growth, pigments and antioxidant pool of bean (Dolichos lablab) under field conditions. J. Environ. Biol. 32: 139-145.

Stracke R, Favory JJ, Gruber H, Bartelniewoehner L, Bartels S, Binkert M, Funk M, Weisshaar B, Ulm R. 2010. The Arabidopsis bZIP transcription factor HY5 regulates expression of the PFG1/ MYB12 gene in response to light and ultraviolet-B radiation. Plant Cell Environ. 33:88-103.

Sun T, Yuan H, Cao H, Yazdani M, Tadmor Y, Li L. 2018. Carotenoid Metabolism in Plants: The Role ofPlastids. Mol. Plant.11: 58-74.

Sunoj VSJ, Shroyer KJ, Jagadish SVK, Prasad PV. 2016. Diurnal temperature amplitude alters physiological and growth response of maize (Zea mays L.) during the vegetative stage. Environ Exp Bot. 130:113-121.

Szymańska R, Ślesak I, Orzechowska A, Kruk J. 2017. Physiological and biochemical responses to high light and temperature stress in plants. Environmental and Experimental Botany. 139:165-177.

Takshak S, Agrawal SB. 2015. Defence strategies adopted by the medicinal plant Coleus forskohlii against supplemental ultraviolet-B radiation: augmentation of secondary metabolites and antioxidants. Plant Physiology and Biochemistry. 97:124-138.

Tatullo M, Simone GM, Tarullo F, Irlandese G, De Vito D, Marrelli M, Santacroce L, Cocco T, Ballini A, Scacco S. 2016. Antioxidant and Antitumor Activity of a Bioactive Polyphenolic Fraction Isolated from the Brewing Process. Sci. Rep. 6: 36042.

Teramura AH, Sullivan JH, Lydon J. 1990. Effects of UV-B radiation in altering soybean yield: a 6-year field study. Physiol. Plant. 80: 5-11

Tessadori F, van Zanten M, Pavlova P, Clifton R, Pontvianne F, Snoek LB, Millenaar FF, Schulkes RK, van Driel R, Voesenek LA. 2009. Phytochrome B and histone deacetylase 6 control light-induced chromatin compaction in Arabidopsis thaliana, PLoS Genet. 5, e1000638.

Tohidi-Moghadam HR, Ghooshchi F, Jamshidpour F, Zahedi H. 2012. Effect of UV radiation and elevated $\mathrm{CO} 2$ on physiological attributes of canola (Brassica napus L.) grown under water defiit stress. Polish Journal of Environmental Studies. 21: 1417-1427.

Topcu Y, Dogan A, Kasimoglu Z, Nadeem HS, Polat E, Erkan M. 2015. The effects of UV radiation during the vegetative period on antioxidant compounds and postharvest quality of broccoli (Brassica oleracea L.). Plant Physiology and Biochemistry. 93:56-65. 
Torres S, Cabrera-Pardo JR, Alonso F, Bustos E, Perez C, Palfner G, Hernandez V, Uriarte E, Becerra J. 2016. Changes in secondary metabolites profiles and biological activity of the fresh fruiting bodies of Stereum hirsutum exposed to highdose UV-B radiation. J. Chil. Chem. Soc. 61(4): 3224-3227

Tossi V, Lamattina L, Jenkins GI, Cassia RO. 2014. UltravioletBinduced stomatal closure in Arabidopsis is regulated by the UV RESISTANCE LOCUS8 photoreceptor in a nitric oxidedependent mechanism. Plant Physiol. 164:2220-2230.

Vandenbussche F, Tilbrook K, Fierro AC, Marchal K, Poelman D, Van Der Straeten D, Ulm R. 2014. Photoreceptormediated bending towards UV-B in Arabidopsis. Mol. Plant. 7:1041-1052.

Verdaguer D, Jansen MAK, Llorens L, Morales LO, Neugart S. 2017. UV-A radiation effects on higher plants: Exploring the known unknown. Plant Sci. 255: 72-81

Vidovic' M, Morina F, Milic' S, Zechmann B, Albert A, Winkler JB, Jovanovic SV. 2015. Ultraviolet-B component of sunlight stimulates photosynthesis and flavonoid accumulation in variegated Plectranthus coleoides leaves depending on background light. Plant, Cell and Environment. 38: 968-979.

Virjamo V, Sutinen S, Julkunen-Tiitto R. 2014. Combined effect of elevated UVB, elevated temperature and fertilization on growth, needle structure and phytochemistry of young Norway spruce (Picea abies) seedlings. Glob. Change Biol. 20: 2252-2260.

Wang H, Gui M, Tian X, Xin X, Wang T, Li J. 2017. Effects of UV-B on vitamin $\mathrm{C}$, phenolics, flavonoids and their related enzyme activities in mung bean sprouts (Vigna radiata). International Journal of Food Science and Technology. 52 (3): 827-833.

Wang PC, Mo BT, Long ZF, Fan SQ, Wang HH. 2016. Factors afecting seed germination and emergence of Sophora davidii. Ind Crop Prod. 87:261-265.

Wang Y, Xu WJ, Yan XF, Wang Y. 2011. Glucosinolate content and related gene expression in response to enhanced UV-B radiation in Arabidopsis. African Journal of Biotechnology. 10: 6481-6491.

Wargent JJ, Gegas VC, Jenkins GI, Doonan JH, Paul ND. 2009. UVR8 in Arabidopsis thaliana regulates multiple aspects of cellular differentiation during leaf development in response to ultraviolet B radiation. New Phytol. 183:315-326.

White AL, Jahnke LS. 2002. Contrasting efects of UV-A and UV$\mathrm{B}$ on photosynthesis and photoprotection of $\beta$-carotene in two Dunaliella spp. Plant \& Cell Physiology (PCP). 43 (8): 877884 .
Winter TR, Rostas M. 2008. Ambient ultraviolet radiation induces protective responses insoybean but does not attenuate indirect defense. Environ. Pollut. 155: 290-297.

Wu D, Hu Q, Yan, Z, Chen W, Yan CY, Huang, X, Zhang J, Yang PY, Deng HT, Wang JW, Deng, XW, Shi YG. 2012. Structural basis of ultraviolet-B perception by UVR8. Nature 484: U214-U296.

Wulff A, Anttonen S, Pellinen R, Savonen EM, Sutinen ML, Heller W, Sandermann Jr H, Kangasjärvi J. 1999. Birch (Betula pendula Roth.) responses to high UV-B radiation. Boreal Environment Research. 4: 77-88

Xie Y, Zhang W, Duan X, Dai C, Zhang Y, Cui W, Wang R, Shen W. 2015. Hydrogen-rich water-alleviated ultraviolet-Btriggered oxidative damage is partially associated with the manipulation of the metabolism of (iso) flavonoids and antioxidant defence in Medicago sativa. Functional Plant Biology. 42: 1141-1157.

Xie Y, Yang W, Tang F, Chen X, Ren L. 2015. Antibacterial activities of flavonoids: structure-activity relationship and mechanism. Curr Med Chem. 22 (1):132-49.

Xu GL, Singh SK, Reddy VR, Barnaby JY. 2016 Soybean grown under elevated $\mathrm{CO}_{2}$ benefts more under low temperature than high temperature stress: varying response of photosynthetic limitations, leaf metabolites, growth, and seed yield. J Plant Physiol. 205:20-32.

Yang DL, Sun P, Li MF. 2016. Chilling temperature stimulates growth, gene over-expression and podophyllotoxin biosynthesis in Podophyllum hexandrum royle. Plant Physiol Biochem. 107:197-203.

Yang Y, Yang X, Jang Z, Chen Z, Ruo X, Jin W, Wu Y, Shi X, $\mathrm{Xu}$ M. 2018. UV RESISTANCE LOCUS 8 From Chrysanthemum morifolium Ramat (CmUVR8) Plays Important Roles in UV-B Signal Transduction and UV-BInduced Accumulation of Flavonoids. Front Plant Sci. 9: 955.

Yin R, Ulm R. 2017. How plants cope with UV-B: from perception to response. Curr Opin Plant Biol. 37:42-48.

Young AJ, Lowe GL. 2018. Carotenoids-antioxidant properties. Antioxidants 7:28-31.

Zagoskina NV, Dubravina GA, Alyavina AK, Goncharuk EA. 2003. Effect of ultraviolet (UV-B) radiation on the formation and localization of phenolic compounds in tea plant callus cultures. Russian Journal of Plant Physiology. 50(2): 270275.

Zu Y, Li Y, Chen J, Chen H. 2004. Intraspecific responses in grain quality of 10 wheat cultivars to enhanced UV-B radiation under field conditions. J. Photochem. Photobiol. B Biol. 74: 95-100. 